\title{
Some reflections on the theoretical concepts involved in corporate governance - the moral and philosophical aspects
}

\begin{abstract}
This article presents a theoretical concept of the foundation of company organisations and their nature as a function of corporate governance. The author discusses the moral, philosophical and theoretical foundations of corporate objectives from the perspective of reviewing theoretical considerations of ownership, rights and control since these are at the base of the experience of all organisations, from whatever level of economic development, as regards the concept of corporate governance. Particular issues connected with this concept include the institutional framework and the development of capital markets. The article is based on historical research and presents a deepening of our theoretical knowledge of corporate governance, with a focus on property, the nature of the company and its moralphilosophical aspect and also the implications of the separation of ownership from management. The influence of ownership within a corporate structure should necessarily be significant, since the entire process of management gains its origins from the ownership structure.
\end{abstract}

Keywords: nature and theory of firms, corporate governance, objectives, ownership, division of labour, property, financial markets, moral-philosophical aspects, separation of ownership and management, conflicts of interest

Introduction

To understand the nature of the firm, a corporation, it is necessary to understand the concepts behind its foundation since this is the base of everything. Problems in our understanding cannot be solved unless we know their nature and, in this context, this means how society reacts to the nature and purpose of the company, issues of corporate governance, etc.

This article is one part of a wider review of the literature on company organisation developed for a doctoral dissertation on Corporate governance and its impact on the performance of the company. It gives a historical overview of the origins of ownership, the firm and people's need to associate with each other; the nature, theory and objectives of firms; the role and implications of the separation of ownership from management; and financial systems based on capital markets from the perspective of corporate governance.

The subject of the research and critical analysis will be the theoretical assumptions on, and the methodological solutions to, the above concepts and the implications of such developments. The consequences of the separation of ownership and control 
within corporations has resulted in the system's need for corporate governance processes.

This article discusses the moral, philosophical and theoretical foundations of corporate objectives. The focus is on different interpretations of the aims of the firm in different social environments. It reviews the theoretical considerations of corporate ownership and control - to whom a corporation belongs, what its goals are and who manages it.

Richard Swedberg, in his book Principles of Economic Sociology, says that a large part of economic life can be seen in terms of economic organisation, or with a perspective that shows how people, institutions and material objects are both connected to and separated from each other. That is, we can not fully understand the dynamics of different types of economic organisation if we do not understand that their structures are the result of a combination of interests and social relationships (Swedberg, 2006).

According to Max Weber, it is human interests that drive action, but the social component determines how those actions will be expressed and directed. Interests can be both material and conceptual. All interests are social in two ways: firstly, they are all part of the society into which the individual is born; and, secondly, one must take account of other stakeholders who are trying to realise their own interests.

We need better to understand human nature, because the only real danger that exists is man himself... He is the great danger, but we are unfortunately unaware of it. We know nothing about man. His psyche should be studied, since we are the root of all coming evil. (Carl Gustav Jung)

Every corporation, regardless of the level of development of the economy in which it operates, encounters the same problems regarding corporate governance. These are: ownership; shareholders' rights; and control.

\section{Theoretical framework}

History shows that individuals and their endeavours and discoveries have moved mankind forward while, in addition, knowledge has been dispersed. Making sense of how that can be combined and exploited is the issue to which philosophers of different persuasions have addressed themselves.

\section{Community development}

Erich Fromm, ${ }^{1}$ who has focused his research on the psychological aspects of human existence, says that the structure of a society consists of engineering, technology, property, specific organisations and appropriate cultures.

In primitive society, i.e. in a society based on a clan system, there was no organised power. The development of material productive forces, the division of labour, the expansion of trade and establishment of markets, the appearance of private property and the splitting of tribal organisations into owners (rich) and non-owners (poor) collapsed

1 Erich Fromm (1900-1980) was a German social psychologist, sociologist and humanist philosopher. 
the clan system. On the ruins of old tribal communities grew new social organisations with antagonistic classes in existence. The result of the irreconcilability of the classes was the creation of the state.

The division of labour is a fundamental structural principle of entire societies. The importance of the division of labour was first noticed by Plato, who observed everyone performing work in accordance with their abilities. The division of labour broke up initial forms of society.

Adam Smith explains the division and development of labour solely from the standpoint of economic policy objectives which are set out from an interest in the higher productivity of human labour.

The division of labour was seen by Marx as a factor leading to separation within society. The division of labour emerged as a necessity from which certain forms of social structure, social organisation and social institutions arose. This was the result of the productive activity of human beings, not an innate trait of human nature.

The historical development of society based on the division of labour led to the emergence of private property, a division between intellectual and physical labour and division between village and city, which is one of the oldest divisions but which is still maintained. Private property is the most important form of social (in)equality among people. The division of labour, property and the achieved level of the development of funds influence the structural character of the whole society as well as the nature of social relations in general. Property is a historically variable social institution.

\section{Property and ownership}

The Roman conception of property rights was that property rights meant a complete authority over things. More concurrently, the Marxist conception of property rights is that:

Every production is an appropriation of nature by an individual within the established social forms.

Ownership is the legal term for the processes of economic production and appropriation; while ownership means the right of an individual or a group to make decisions about the use of property ownership. When these forms are socially sanctioned and protected, they become 'rights'.

The division of property and its public constraints give rise to the formation of a number of specific forms of ownership. There are mainly two kinds of property: private property and collective property. (Labus, 2007)

However, today's understanding of property is set in the context of the nineteenth century, i.e. in the age of liberalism, and corresponds the most with the Roman understanding of the concept of ownership.

Property rights and their protection are important since ownership is the basis for managing and gaining control over company organisations. From the point of view of 
the enterprise, ownership is an important legal institution since it is the basis for direct control over operations in the company (Labus, 2007).

Hernando de Soto, in his book The Mystery of Capital, has been engaged in research into property rights and the institutional infrastructure of a society based on free market principles (de Soto, 2000). He presents the role of the system of property rights as a functional property system that allows full economic potential to be exploited; and secondly, that arranged property relationships change the social capital of a country, making people into accountable individuals who no longer have to rely primarily on traditional local communities to protect their property rights.

Can we understand that life, freedom and property do not exist because men have created law. On the contrary, the fact that life, liberty and the property had existed before just led people to create laws. Life, liberty and property do not adapt to laws, but laws should arise from the need to protect three key human rights: the right to live; the right to liberty; and the right to property. Each of us has a natural right, according to Bastiat, to defend his own liberty and property. (Vukotić, 2004)

The key question implied here in terms of corporate organisations is how the ownership structure of a company and the actual content of property rights affect the efficient functioning of that company? Consequently, ownership structure and contractual arrangements, between actual or potential business partners, now represent a significant organisational phenomenon, and any study of the specific organisation of a company is incomplete if this problem is not considered. The only truly effective system is a system of private property rights.

\section{Historical aspects of financial markets}

The company as a business entity appeared in the fifteenth century, subsequent to the separation of the assets of the business from the entrepreneur's private property. Such companies became independent economic entities under their own name and could be bought and sold. The concept of entrepreneurship has been known since the twelfth century, while creative entrepreneurship has been massively developed since the seventeenth century. At the point at which an entrepreneur permanently and continuously starts to carry out entrepreneurial functions, the form of the company was created to reflect the performance and organisational structure of the economic activity being carried on.

Corporate governance is as old as corporations or joint stock companies. According to some authors, the first joint stock companies were created back in the seventeenth century, when huge concentrations of capital were required in order to build trade and military ships, and for the exploitation of the newly-conquered colonies by the established overseas colonial societies. The first such society was the Dutch East India Company, formed in 1602 by a merger of the commercial business activity owned by several cities which, due to dissatisfaction with the untimely and incomplete information being provided about the business, formed in 1623 the first monitoring committee to protect their interests. Subsequently, the model was extended to similar companies in France and England. This company started its work with 218 members (or share- 
holders) (Vasiljević, 2007) and its established form of organisation later spread to other areas: maritime trade; banks; and insurance.

All the evidence suggests that the Mediterranean is the cradle of the stock company. (Braudel, 1992)

The medieval Italian city-states, primarily Venice and then Florence, Genoa, Verona and others, aired the first debt securities in order to settle ongoing financial needs and, at the same time, to avoid an unpopular tax increase. Indeed, the first bank (Banco di San Giorgio) was founded in Genoa in 1407.

In 1724, the Paris Stock Exchange was established by decree and, in March 1801, the London Stock Exchange was formally created not only as a place to trade but also as a place in which the rules of business were settled. The fundamental difference between the London and the Paris stock exchanges is that the London Stock Exchange was self-regulatory and, as such, was created according to the requirements of the market and the participants (as opposed to the Paris Stock Exchange, which was established as a need of the French state and controlled by the French government).

The whole period of the 1840s was marked by the growth of volume market material around the world's stock exchanges, the opening of new markets and the establishment of new joint stock companies, as well as the rise in the banking sector at the local level. By 1900, there was no continent immune from securities and, therefore, stock markets. Around World War I, the New York Stock Exchange became the dominant market in the United States.

The weaknesses in corporate governance have been at the root of all major financial crises. Up until now, it has reflected the most classic expropriation of shareholders' property and the weaknesses of oversight regimes (authority boards). With the McFadden Act of 1927, US states sought to regulate the expansion of the banking business through subsidiaries. This led to a massive speculative boom that ended in 1929 with the Great Depression (the downfall of Wall Street), a period of decline which finished only in July 1932. The US federal government subsequently brought in laws in order to regulate the operations of the stock market: chiefly, the Securities Markets Law (Securities Exchange Act), adopted in 1933 and which first set down the Securities and Exchange Commission as a market regulator in 1934.

The financial markets were in a globalisation process and, in 1962, the International Federation of Stock Exchanges (FIBV), now called the World Association of Stock Exchanges (WFE: World Federation of Exchanges), was formed.

The eighties, on the basis of technological innovations, brought in a number of changes that facilitated public pressure on individual national financial markets that were already highly globalised. The last thirty years have seen drastic changes in the field of telecommunications, given the advent of information and communications technologies which have advanced globalisation processes even further.

Historically, the development of the field has moved in parallel with the evolution of social relationships and the development of the political system. For example, the idea of the annual general meeting followed the French Revolution (1789); while the right of the free establishment of joint stock companies (excluding government con- 
cessions) developed at the end of the nineteenth century (1892), many of them implemented in continental Europe prior to World War II. However, the literature points out that the first legal regulation of a joint stock company was the French Code de Commerce from 1807.

Corporate governance has increasingly gained in importance as a result of the Asian crisis in 1987 (the inadequate supervision of brokers and trade led to Black Monday and a stock market crash); the Russian crisis in 1998; and corporate scandals and bankruptcies during 2001 (Enron) and 2002 (WorldCom). These provoked the adoption of the Sarbanes-Oxley Act on corporate governance in the United States in 2002, as well as recommendations for corporate governance codes in many countries both then and after the outbreak of the global financial crisis in 2008 (Lehman Brothers).

Corporate governance has a long presence in developed countries as a concept and practice, but the completion and rehabilitation of mechanisms of corporate governance have taken place in the last few years. Today, corporations are the most complex organisational form of companies.

All this suggests that the history of joint stock companies and the history of contemporary capitalism (now the innovative information era) are intertwined and that changes in the functioning of the modern corporation, and therefore the problems that have been encountered, reflect changes in the development of modern society.

\section{The nature and the theory of the firms and corporations}

In answering questions about the nature and theory of firms, we are looking at questions about why firms exist, why they are established and what their goals are.

The theory of the firm should offer answers to basic questions about the essence of a company, the reasons for its establishment, the limits of its size, etc. It should be a source of ideas for resolving theoretical and practical problems, thus representing one of the pillars of modern economics.

Based on Oliver Williamson's opinion, the firm is mainly a mechanism of management (Williamson, 1975).

Ronald Coase's influential 1937 article on 'The Nature of the Firm' provides an economic explanation as to why some individuals choose to form partnerships, companies and other business entities. It also offers useful thoughts on the purposes of discovery and a clarification of the significance of transaction costs and property rights for institutional structure and the functioning of the economy.

Enterprises create value, assuming a wide range of social roles and tasks, although the main purpose of an enterprise is economic efficiency and performance in order to create profit. The issue of uncertainty is often considered to be highly relevant to a study of the balance of the firm. If there was no uncertainty, the concept of the firm would probably not have emerged (Coase, 2000: 39). Entrepreneurship is the act of taking risks against the uncertainty of the future. If the future were known, no-one would take any action. Thus, the overall behaviour of mankind has been constructed on the basis of an assumption of a struggle with uncertainty regarding the realisation of a goal which is considered to have potential for an improvement on the current situation. 
Firms appear on the market so as to reduce the transaction costs that arise between a firm's organisers and the factors of production which it deploys (Coase, 2000: 67). The main activity of firms is, of course, managing work. Furthermore:

We should not forget that, as long as we live in a world where what we have is less than what we want, nothing is more humane than a quick removal of unproductive enterprises through minimal transaction costs. (Pejović, 2004)

Coase's concept of the firm is practical because it uses standard economic theory in the analysis of a firm's activities. His assumption was that a firm develops as a result of an imbalance between the costs of using of information from the free market and the managerial costs of doing business.

However, his primary division of the firm into transactions and transactions conducted in the market may today be considered to be quite a simplistic approach.

The firm is a changeable entity, representing a flexible network of contractual relationships between individuals and groups who have different interests, who make different contributions to the firm and who have different motivations concerning it.

However, corporate governance and the contractual relationships that are at the core of a firm need not be in conflict.

The importance of an adequate organisational structuring of the enterprise is also the view of Peter Drucker: ${ }^{2}$

All organizational units of an enterprise must be connected and integrated so they can act homogeneously and in an aligned way. This unique system of the organizational units of the enterprise is called its organizational structure.

Can the management of modern organisations function without any changes? The answer is no: not just top management but today all levels of management are faced with complexity and change.

Once established, the organisational structure of an enterprise may not be sufficient over a long time and certainly not permanently. Constant changes in the market environment and in overall management are the imperative for a continuous improvement in the organisational structure of the enterprise, with the aim of acquiring, preserving and improving its market position. This is the point that indicates the importance of corporate governance principles. Future organisations should have an established corporate culture, so as to be ready for the implementation of organisational changes.

To be successful in the era of information and communications technology, an organisation must include in its structure the management of change; i.e. the organised abandoning of everything it used to do, but also the ability to create a new strategy.

2 Peter F. Drucker (1909-2005) was a professor, economist, writer and management consultant. He worked with many major corporations (including General Electric, Citicorp, Coca Cola, IBM and Intel). 


\section{Moral and philosophical aspects}

Companies are institutions which are a reflection of the maturity of a society. In turn, the maturity of a society is indicated by the maturity of the individuals that live within it.

One group of authors, referring to Adam Smith, emphasises the entrepreneurial nature and function of the corporation and the irreplaceable role of individuals and their needs and interests in economic life. Another group of authors refers to Chief Justice Marshall's 1819 definition:

A corporation is an artificial, invisible, intangible being which exists only in the minds of lawyers and the law.

Accepting this kind of definition points to the dual nature of the corporation: on the one hand, it is an artificial construct, bestowed by law; and, on the other, it has the power and duties of natural beings arising from the separate identity with which it is endowed. Like humans, a corporation can own property, have debts and claim debts in court. However, we should emphasise the natural character of those human beings who lead a company's policy and make its decisions. These beings are the managers who do not directly own any part of the corporation's assets.

The behaviour of firms, as well as their objectives, are determined by systems of social values. The role of the firm's mission is linked to the development of a desirable corporate culture and identity-building among enterprises.

The task of the theory of the firm, and economic science in general, is not to find what is ethically right, but it must take into account ethical postulates as economically relevant because they are part of the environment which surrounds the corporation and which therefore affect the quality of its decision-making.

The political framework which reflects the philosophical and moral values of a society define the limits within which range the other institutions of the social system. When we talk about corporate governance and the goals of the firm, we may wonder if the objectives of the firm are formally predetermined by the broader social context or whether they are the result of spontaneous order? The answer to this question depends on the individual's philosophical or scientific orientation. An explanation of the phenomena of the social system of institutions, in this case of the governance of corporate institutions, helps to clarify the essence of company objectives within different systems of corporate governance.

When it comes to responsibility for the running of a firm, this refers to two types of obligation - the obligation to undertake certain activities (resource management); and the obligation to be accountable for activities (via annual reports and financial statements). The basic elements of liability arising from the relationship between directors and shareholders refer to how the company defines its laws and the informal rules that apply. Therefore, corporate governance is the total values of a company, depending on the role that society assigns to the firm; that is, the nature of the 'contract' between state, individuals, businesses, the environment and other stakeholders.

The world view and understanding of the role of corporations in society may be explained using the postulation of Friedman, according to which: 
In a free-enterprise, private-property system, a corporate executive is an employee of the owners of the business. He has direct responsibility to his employers. That responsibility is to conduct the business in accordance with their desires, which generally will be to make as much money as possible while conforming to the basic rules of the society, both those embodied in law and those embodied in ethical custom. (Friedman, 1970: 122)

In this view, the main objectives of firms are economic efficiency and the making of a profit - albeit within the purview of the legal and the ethical, while they must also act with integrity. So, the aims of the company have been expanded from the property (and the financial) to the social and the public.

Corporate governance has, consequently, come to be seen as an area which reflects the institutional shaping of EU regulations according to the range of moral, philosophical, cultural and political traditions and the impact that these have had on the European continent.

Joel Bakan, in his book The Corporation: The Pathological Pursuit of Profit and Power, seeks to prove that the corporation is a pathological institution, a dangerous possessor of great power over people and society. Today indeed, the main problem of companies listed on the stock exchange, is their perverse institutional character (Bakan, 2006).

The two key, and failed, mechanisms of corporate governance which caused the financial crisis in 2008 - making 30 million unemployed and bringing some countries to the brink of insolvency - are as follows:

1. risk management and control and auditing systems

2. boards of directors in charge of companies but which are separated from ownership. Addressing these failures of corporate governance are the most important contributions which can be made to understanding and re-interpreting the role of corporate organisations in modern life.

\section{Implications of the separation of ownership from management}

Management is as old as civilisation. Corporate governance is one of its most significant aspects which aim to direct an organisation towards the achievement of its planned objectives. Corporate governance - or collective decision-making, based on 'joint management' or 'management by several people' - is not an end in itself, but is a means to an end and is a key element of market mechanisms rooted within the concept of competition.

The relationship between corporate governance and the level of maturity of an individual concerns the maturity with which the profit motive is viewed:

The key objective of capitalism is profit and stakeholders will use culture and organisation and networks, all in the search for profit. Profit is constantly being reinvested in new production. (Drucker, 2005: 82)

Adam Smith in his Wealth of Nations notes that, in a 'private trading society', responsibility is for individuals' 'own wealth'; while in a joint stock company', re- 
sponsibility is only in proportion to the amount that the individual has invested. This leads to a significantly higher risk in the first case than in the second.

In turn, Weber points out that modern capitalism might be more efficient (from the viewpoint of the owner) if the managers, and not the owners, would leave the management of corporations. The original owner and creator of a company may have once been a skilled manager, but it is less likely that his successors will be the same, unless they have been particularly carefully selected.

The issue of the separation of ownership and control is thus very firmly within the purview of our questioning: who controls the corporation is an issue which is continually present in contemporary social sciences and is subject of interest from various disciplines and political perspectives.

From the perspective of the objectives of firms, the separation of ownership and control means that managers may well seek to implement objectives which greatly differ from the goals that were previously carried out by the owners of the corporation.

Williamson's view of the separation of ownership and control and the rise of large corporations (inspired evidently by Coase's work) is that these are derived not from an assumption of managerial control, but based on the internalisation of those transactions that were previously performed in the capital market which, due to organisational innovation, now take place within the organisation.

Modern bureaucracy, as Max Weber has commented, has been preceded by a series of separations - from the separation of workers from the means of production to the separation of ownership from control.

From the perspective of corporate governance, the interests of capital owners within a corporation must be protected by the managers and the directors: ownership continues to be the basis for managing and gaining control of enterprises, while shareholders' rights arise out of their ownership of enterprises. Control of a company is, therefore, a basis for sustaining the interests of the shareholders.

Theory goes on to state that the issue of corporate governance is reflected in three specific agency problems. The first of these three - the initial conflict of interest between shareholders and management; that is, the level of control of company shareholders over management - was pointed out by Adam Smith in the eighteenth century (Smith, 1776). He emphasised that, on the one hand, we should be wary of passive shareholders and, at the same time, of the extravagance of leaders responsible for managing other people's capital. The separation of ownership from management may result in risks to a company where it is managed solely in the interests of short-term success in order to be profitable in a relatively short period of time. This is particularly the case where managers have created a salary and bonus structure for themselves which ignores the long-term interests of the company and its shareholders, or which may even work directly against them. This problem does not, however, essentially lie in the separation of ownership from management but in the dispersal of the shareholder structure, in which a large number of small shareholders are not able to influence decision-making and the management of the company.

The second agency issue in corporate governance is reflected in the existence of a conflict of interest between the majority shareholder (or majority shareholders where there are voting agreements in place) and minority shareholders. This constant problem 
may be resolved by improving corporate governance in general and by improving the rights of minority shareholders.

The third agency issue lies in the relationship between the society at hand (i.e. the controlling shareholder in the company and/or the administration) and the other stakeholders in the company's business (i.e. the remaining risk-bearers).

The relationship between enterprises and their shareholders is determined by the nature of property rights constituted within the enterprises. However, the separation of ownership and control (on behalf of the principal agent) leads to a separation between risk-bearing and decision-making. Corporate governance aims to resolve (or otherwise mitigate) the principal-agent problem arising from the separation of ownership and management, or from control over the finances.

\section{Conclusion}

This article has provided a brief historical overview of the most important and most influential events that have marked the historical development of property, the nature of the firm and the implications of the separation of ownership from management. Welldefined private property rights are the key to future progress since, ultimately, it is property rights that have the greatest importance. The influence of ownership within a corporate structure should necessarily be significant: the entire process of management has been given birth from the ownership structure and, in the end, corporate culture is built up from ownership structure.

The issues connected with corporate governance include the institutional framework; factors in the development of the capital market (the development of private property, cultural development, economic development and political development); and the assumption of developments on the capital market (changes in the current system, particularly in the governance, management and evaluation of business enterprises) or, in short, the construction of the capital market.

A corporation is a legal invention, reflecting social and economic mechanisms for the concentration and deployment of human and economic power. The role of the corporation is to make a profit for its investors; as an entity, it has no other purpose and neither does it recognise any other values.

Nevertheless, historical developments show us that circumstances, the interests of people and the way they think in a particular period of time and over the establishment of certain companies demonstrates the outcomes of a battle between significant interests.

A study of the concentration of ownership indicates a high level of separation of ownership and control, while problems in the system of corporate governance occur where the safeguards of individual entities are at the weakest. At the same time, a number of historically significant events and facts have made a substantial impact on the development of stock exchanges and financial markets as we know them, as well as the foundations on which they have developed and the other conditions which have emerged for their development.

This has always been the case in history and, even today, these still affect future processes of development and organisational form. 


\section{References}

Bakan, Joel (2006) Korporacija: patološka težnja za profitom i moći Mirakul: Zagreb

Berle, A. Jr. and G. Means (1932) The Modern Corporation and Private Property Macmillan.

Braudel, Fernand (1992) The Wheels of Commerce (Civilization and Capitalism: 15th - 18th Century, Volume 2), University of California Press.

Coase, Ronald (2000) 'Priroda firme' in Oliver Williamson and Sidney Winter (Eds.) Priroda firme - porijeklo, evolucija i razvoj CID: Podgorica.

De Soto, Hernando (2000) Misterija kapitala.

Drucker, F. Peter (1946) Koncept korporacije John Day: New York.

Drucker, F. Peter (1991) ‘Inovacije i preduzetništvo’ NIP Privredni pregled Beograd.

Drucker, F. Peter (2005) Upravljanje u novom društvu Adižes: Novi Sad.

Friedman, Milton (1970) 'The Social Responsibility of Business is to Increase its Profits' New York Times Magazine 13 September 1970.

Freud, Sigmund (2006) Psihologija mase i analiza ega Fedon: Beograd.

Jung, G. Carl (1978) Psihološki tipovi Matica srpska: Beograd.

Labus, Miroljub (2007) Svojina: pravna osnova tržišnih odnosa Pravni fakultet: Beograd.

Mises, von Ludvig and Friedrich Hayek (1997) O slobodnom tržištu klasični eseji, Mate: Zagreb.

Pejović, Svetozar (2003) 'Why is culture important?' Zbornik Postdiplomskih studija Preduzetnička ekonomija Volume II, Podgorica.

Pejović, Svetozar Stiv (2004) 'Dva modela' Ekonomist 190, 12. 01. 2004.

Pejović, Svetozar and Veselin Vukotić (2002) Tranzicija i institucije Zbornik radova, Institut društvenih nauka: Beograd.

Schumpeter, A. Joseph (1998) Kapitalizam, socijalizam i demokratija Plato: Beograd.

Smith, Adam (1776) Bogatstva naroda Global Book: Novi Sad.

Stigler, G. J and C. Friedland (1983) 'The Literature of Economics: the Case of Berle and Means' Journal of Law and Economics XXVI(2).

Swedberg, Richard (2006) Načela ekonomske sociologije Mate: Zagreb.

Vasiljević, Mirko (2007) Korporativno upravljanje - pravni aspekti Beograd.

Vukotić, Veselin (1993) Privatizacija - put u tržišnu privredu Institut društvenih nauka: Beograd.

Vukotić, Veselin (2004) Politička ekonomija ekonomskih sloboda ISSP: Podgorica; IDN: Beograd. 
Vukotić, Veselin (2009) Sloboda, znanje, tržište: tržište vs. funkcionalna pamet Podgorica.

Vukotić, Veselin (2011) Istorija budućnosti CID: Podgorica.

Weber, Max (1989) Metodologija društvenih nauka Globus: Zagreb.

Williamson, Oliver (1975) Korporativna kontrola i poslovno ponašanje.

Williamson, Oliver and Sidney Winter (2000) Priroda firme - porijeklo, evolucija $i$ razvoj CID: Podgorica. 